\title{
Comparative Assessment of the Effect of Ripening Stage on the Vitamin C Contents of Selected Fruits Grown within Nsukka Axis of Enugu State
}

\author{
Ezeh Ernest $^{1}$, Okeke Onyeka ${ }^{2}$, OzuahA.C. ${ }^{3}$, Onwubiko R.O. ${ }^{4}$ \\ ${ }^{1}$ Chemical Engineering Department, Nnamdi Azikiwe University, Awka. \\ ${ }^{2}$ Plastic Production Unit, Sedi-Enugu. \\ ${ }^{3}$ Integrated Science Department, Nwafor Orizu College of Education, Nsugbe. \\ ${ }^{4}$ Advanced Manufacturing Unit, Sedi-Enugu.
}

\begin{abstract}
Studies were carried out on the quantitative determination of vitamin $C$ in fresh fruits (orange, cashew, pawpaw, lemon, grape) at different ripening stages using iodometric titration method. The study revealed that the vitamin $C$ contents in the fruits at different ripening stages decreased in the following order: half-ripe < ripe < unripe. Orange was found to have the highest vitamin $C$ content of $77.96 \pm 0.44 \mathrm{mg} / 100 \mathrm{~g}$ while lemon has the least content of the vitamin with a value of $11.83 \pm 0.10 \mathrm{mg} / 100 \mathrm{~g}$.
\end{abstract}

Keywords - Vitamin C, Ripening effect, Cashew, Orange, Lemon, PawPaw and Grape.

\section{INTRODUCTION}

Fruit is a part of flowering plant derived from specific tissues of the flower, with one or more ovaries and in some cases accessory tissues (Mauseth, 2003). Fruits are the means by which plant disseminate seeds. Many plants bear edibles fruits. Humans and animals have become dependent on fruits as a source of food and hence accounts for a substantial fractions of the world's agricultural output (Lewis, 2002). Example of fruits include; mango, apple, cashew, orange, grape, water melon, lemon and pineapple e.t.c.

Cashew (Anarcadium occidentale) is a tropical evergreen tree that produces the cashew nut and cashew apple. It can grow as high as $14 \mathrm{~m}$ and has proved more profitable with earlier maturity and higher yields. The cashew apple is a light reddish to yellow fruit whose pulp can be processed into a sweet, astringent fruit drink or distilled into liquor (Vaughae, 2005). Grape fruit (Citrux paradix) is a subtropical fruits tree known for its sour to semi-sweet fruit.Grape fruit is a hybrid originating in barbados as an accidental cross between two introduced sweet species, sweet orange and pomelo. The evergreen grape fruit trees usually grow to $5-6 \mathrm{~m}$ tall. The fruit has antioxidant properties (Feller et al., 2000) Lemon (Citrux limon) is a species of small ever green tree in the flowering plant family rutaecea, native to Asia. The tree is ellipsoidal yellow fruit and is used for culinary and non-culinary purposes throughout the world (Morton, 1981). Paw paw tree (Cariaca papaya) is native to the tropics is the Americas. It is a small, sparsely branched tree usually with a single stem growth, 5 to $10 \mathrm{~m}$ tall with spirally averages confined to the top of the fruit. The ripe fruit of the papaya is usually eaten raw without skin or seed. It has both culinary and medicinal uses (Titayi et al., 2008). Orange (Citrus sinensis) is a tropical ever green tree from the flowering plant family of rutaecea. The tree is ellipsodal yellow fruits that serves nutritional requirements of man (Nicolosi et al., 2000).

Most plants and animals have the ability to synthesize vitamin $\mathrm{C}$, the only mammals that are unable to synthesize vitamin $\mathrm{C}$ are premates including man and guinea pigs. Therefore, humans depend on exogenous source of the vitamin which includes fruits and vegetable as well as food supplements (Okiei et al., 2009). Vitamin C is the most important vitamin for human nutrition that is supplied by fruits and vegetables. It is a valuable food component because of its antioxidant and therapeutic properties (Okiei et al., 2009). Ascorbic acid also known as vitamin C, when pure is white crystalline water soluble vitamin found especially in citrus fruits, vegetables and organ meats. The amount of ascorbic acid in plant varies greatly, depending on such factors such as variety, weather and maturity (Rahman et al., 2007).

Vitamin $\mathrm{C}$ is a very important water soluble nutrients, critical for sustaining cellular function. It promotes health in a variety of ways, such as preventing scurvy, promoting bone structure and strength, reducing inflammation and aiding the cardiovascular system through anti-oxidation and improving endothelial cell function (Wannamethee et al., 2006; Naidu, 2003). Vitamin C is crucial for maintaining a healthy body and is involved in over 300 biological processes. It is necessary for the manufacture of collagen (Melissa and Ock, 2016).

The only way humans uptake ascorbic acid is via food. The estimated average requirement and recommended dietary allowance of vitamin C is between $100-120 \mathrm{mg}$ per day (Levine et al., 1999). However, findings suggests that people's need for vitamins and other nutrients vary 
markedly and that to maintain good health, many people need amounts of nutrients much greater than the recommended doses (Klezczewska, 2000).

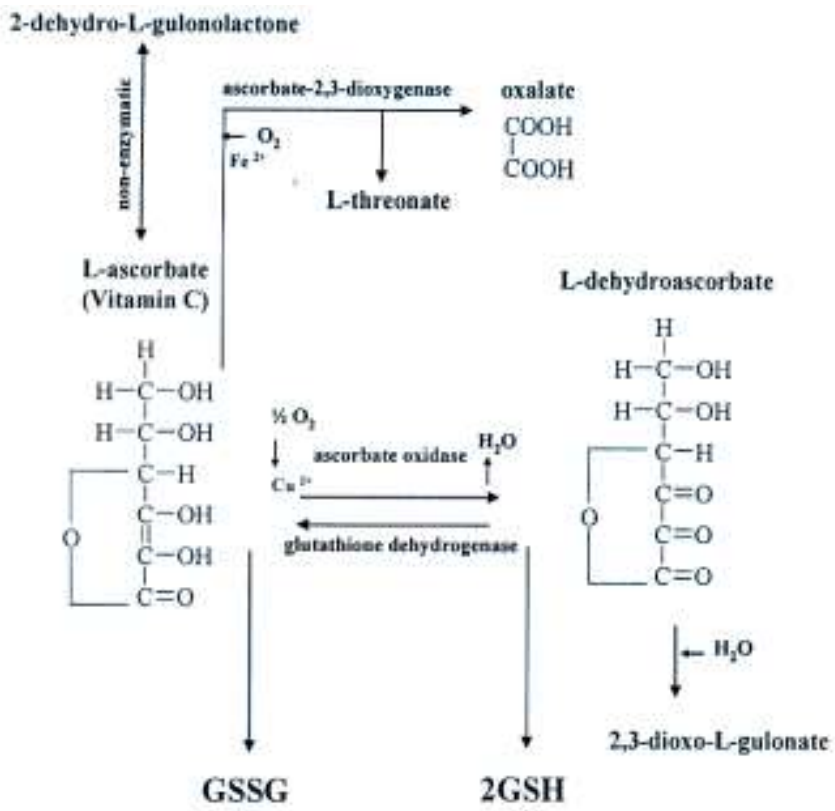

Fig.1: Scheme of a biological function of ascorbic acid (GSH - reduced glutathione, GSSG-oxidized glutathione)(Klezczewska, 2000).

Because of the important role played by vitamin $\mathrm{C}$ in the wellbeing of man and animals as a very important nutrient requirement, studies were carried out to assess the effects of ripening stage on the vitamin $\mathrm{C}$ contents of selected edible fruits grown within the Nsukka axis of Enugu State.
II. MATERIALS AND METHODS

\section{Sample Collection and Preparation}

Twenty five samples (ripe, half-ripe and unripe) were obtained from markets and farms within the studied environment. The fruit samples were; orange, lemon, grape, cashew and paw-paw. Fruits sample were blended with a blender and filtered using a muslin cloth and made up to $100 \mathrm{ml}$ with distilled water respectively.

\section{Preparation of reagents and estimation of ascorbic acid}

$1 \%$ starch indicator solution was prepared by dissolving $0.50 \mathrm{~g}$ soluble starch with $50 \mathrm{ml}$ of distilled water and the solution constantly stirred until it dissolves completely (Harris, 2000).

Iodine solution was prepared by weighing $5.00 \mathrm{~g}$ of potassium iodide $(\mathrm{KI})$ and $0.262 \mathrm{~g}$ of potassium iodate into a $300 \mathrm{ml}$ beaker and dissolving with $200 \mathrm{ml}$ distilled water. $30 \mathrm{ml}$ of $3 \mathrm{M}$ concentration of $\mathrm{H}_{2} \mathrm{SO}_{4}$ was added into the beaker solution was made up to mark with distilled water (Harris, 2000).

Vitamin C standard solution was prepared by dissolving $0.250 \mathrm{~g}$ of ascorbic acid in a $100 \mathrm{ml}$ conical flask with distilled water. The solution was transferred into $250 \mathrm{ml}$ volumetric flask and made up to mark with distilled water.

Titration of iodine solution with vitamin C standard solution was done by pipetting $25 \mathrm{ml}$ into a $125 \mathrm{ml}$ Erlenmeyer flask. 10 drops of $1 \%$ starch solution was added and then titrated against iodine solution until blue-black colour was observed. Each sample was run three times to obtain triplicates measurements and ascorbic contents were evaluated accordingly (Harris, 2000).

\section{RESULTS AND DISCUSSION}

Table.1: below showed the vitamin contents in Table $1(\mathrm{mg} / \mathrm{lo0})$ for the fruit sample analyzed.

\begin{tabular}{llcl}
\hline Fruits & Ripe & $\begin{array}{c}\text { Average concentration of vitamin } \mathbf{C}(\mathbf{m g} / \mathbf{1 0 0 g}) \\
\text { Unripe }\end{array}$ \\
\hline Grape & $30.13 \pm 0.96$ & $39.08 \pm 0.11$ & $20.78 \pm 0.15$ \\
Lemon & $11.83 \pm 0.10$ & $20.12 \pm 0.60$ & $16.45 \pm 0.20$ \\
Pawpaw & $61.09 \pm 0.62$ & $68.69 \pm 0.19$ & $50.14 \pm 1.93$ \\
Orange & $64.85 \pm 1.05$ & $77.96 \pm 0.44$ & $48.85 \pm 0.37$ \\
Cashew & $34.61 \pm 0.74$ & $42.82 \pm 0.33$ & $29.05 \pm 0.18$ \\
\hline
\end{tabular}

The results of vitamin C contents (mg/100g) obtained from the study are indicated in Table 1 . The mean values of the vitamin $\mathrm{C}$ contents decreased in the following order: orange $>$ paw paw $>$ cashew $>$ grape $>$ lemon. Orange was observed to have the highest vitamin $\mathrm{C}$ concentration in all the fruits analyzed while lemon has the least concentration. The results obtained is in agreement with literature findings that the major source of vitamin $\mathrm{C}$ are citrus fruits, especially sweet oranges (Okiei et al., 2009). The variation in vitamin $\mathrm{C}$ contains of the analyzed fruits could be due to factors such as variety, weather and maturity (Rahman et al., 2007).

\section{Grape}

The contents of vitamin $\mathrm{C}$ in grape as indicated in Table 1 were in the order: half ripe $>$ ripe $>$ unripe. This implies that half ripe grape has the highest mean vitamin $\mathrm{C}$ content of $39.08 \pm 0.11 \mathrm{mg} / 100 \mathrm{~g}$ while ripe grape has the least concentration of $20.78 \pm 0.15 \mathrm{mg} / 100 \mathrm{~g}$.

\section{Lemon}

The vitamin contents in lemon decreased in the following order: half ripe > unripe > ripe with mean values of $20.12 \pm$ $0.60 \mathrm{mg} / 100 \mathrm{~g}, \quad 16.45 \pm 0.20 \mathrm{mg} / 100 \mathrm{~g}$ and $11.83 \pm$ $0.10 \mathrm{mg} / 100 \mathrm{~g}$ respectively. 


\section{Pawpaw}

The mean concentration of vitamin $\mathrm{C}$ in pawpaw indicated in Table I increased in the following order: unripe < ripe < half ripe with values of $50.14 \pm 1.93 \mathrm{mg} / 100 \mathrm{~g}, 61.09 \pm$ $0.62 \mathrm{mg} / 100 \mathrm{~g}$ and $68.69 \pm 0.19 \mathrm{mg} / 100 \mathrm{~g}$ respectively.

\section{Orange}

The study showed that the mean contents of vitamin $\mathrm{C}$ in the orange samples decreased in the following order: half ripe $>$ ripe $>$ unripe with values of $77.96 \pm 0.44 \mathrm{mg} / 100 \mathrm{~g}$, $64.85 \pm 1.05 \mathrm{mg} / 100 \mathrm{~g}$ and $48.85 \mathrm{mg} / 100 \mathrm{~g}$ respectively.

\section{Cashew}

The result of the vitamin $\mathrm{C}$ contents in cashew as indicated in Table I increased in the following order: unripe < ripe < half ripe with values of $29.05 \pm 0.18 \mathrm{mg} / 100 \mathrm{~g}, 34.61 \pm$ $0.74 \mathrm{mg} / 100 \mathrm{~g}$ and $42.85 \pm 0.33 \mathrm{mg} / 100 \mathrm{~g}$ respectively. The results of this study was in agreement with values reported by (Mahdavi et al., 2010) for the vitamin C contents of orange and lemon fruits in grown local districts of Pakistan. The results of the study showed that fruits at half ripening stage indicated the highest concentration of vitamin $\mathrm{C}$. It has been reported that ascorbic acid contents in fruits decreases upon ripening, temperature increase and time which were attributed to degradation caused by heat and oxidation (Muhammed et al., 2014).

\section{CONCLUSION}

The results obtained in this study showed that fruits are very essential source of vitamin $\mathrm{C}$ to man and animals. The study further indicated that fruits at half-ripe stage contains the highest vitamin $\mathrm{C}$ concentration hence daily consumption of fruits (especially orange and paw paw) at that maturity stage will ensure that people's needs for the vitamin is met on daily basis.

\section{REFERENCES}

[1] Feller P.J., Nickel S. and Lee H.S. (2000). Nutrient content and nutrient labeling of some process Florida citrus juice products. J. Am. Det. Assoc. 90(8): 1079 1084.

[2] Harris D.C. (2000). Quantitative Chemical Analysis. W. H. Freeman \& Company, New York, $5^{\text {th }}$ Edition, pp $83-88$.

[3] Kleszczewska E. (2000). Ascorbic acid-Chemical use toxicity, properties, methods of determination and application in chemical analysis pharmazie, 55: 640644.

[4] Levine M., Romsey S.C., Darowala R., Park J.B. and Wang Y.H. (1999). Criteria and recommendations for vitamin C intake. J. Am Med Assoc. 281: 1415 1423.
[5] Lewis R.A. (2002). CRC Dictionary of Agricultural Sciences. CRC press. ISBN $0-8493-2327-4$. pp $31-33$.

[6] Mahdavi R., Nikniaz Z., Rafraf M. and Jomyban A. (2010). Determination and Comparison of total polyphenol and vitamin $\mathrm{C}$ contents of natural fresh and commercial fruits juices. Parkistan Journal of Nutrition: 9(10): 986-972.

[7] Mauseth J.D. (2003). Botany: An Introduction to plant Biology. Jones and Bentlett press; ISBN $0-7637-$ $2134-4$, pp $271-272$.

[8] Melissa A. and Ock K.C. (2016). Vitamin C and heart health: A review based on findings from epidemiological studies. Int. J. molecular sciences: 17(1328): 1 - 9 .

[9] Morton J.F. (1981). Lemon in fruits of warm climates. Pordue University, pp 160-168.

[10] Muhammed I., Ashirua S., Garba S. and Kanona A. (2004). Effect of ripening stage on the vitamin C contents in selected fruits. Int. J. Agric., Forestry and Fisheries, 2(3): 60-65.

[11] Naidu K. (2003). Vitamin C in human health and disease is still a mystery? An overview. Nutrition Journal, 2:7-11.

[12] Nicolosi E., Deng Z.N., Gentile A., La Malfa, S., Continella G. and Tribulato E. (2000). Citrus phylogemy and genetic origin of important species as investigated by molecular markers. Theoretical and Applied Genetics, 100(8): 1155 - 1166.

[13] Okiei W., Ogunlesi M., Azeez L., Obakachi V., Osunsanmi N. and Nkenchor G. (2009). The volumetric and titrimetric determination of ascorbic acid levels in tropical fruits samples. Int. J. electrochemistry. Sci., 4: 276-287.

[14] Rahman M.M., Khan M.R. and Husain M.M. (2007). Analysis of vitamin $\mathrm{C}$ content in various fruits and vegetables by UV Spectroscopy. Bangladesh Journal of Science Ind. Res., 42(4): 417-424.

[15] Titayi U.P., Zofou D. and Ngcmremeya M.N. (2008). The antimalarial potential of medicine plants used for the treatment of malaria in Cameroonian folk medicine. African J. Trad. Compl and Alt M., 5(3): $302-321$.

[16] Vaughae T.P. Anatomy of the pseudocarp in Anarcadiumoccidentale. Proceedings of plant sciences. 59(5): $252-258$.

[17] Wannamethe S.G., Lowe G.O., Rumhey A., Brockdorfer K. R. and Whincup P.H. (2006). Association of vitamin $\mathrm{C}$ status, fruits and vegetable intakes and markers of inflammation and hemostasis. Am. J. Chin. Nutri., 83: 567 - 574. 